\title{
Glutathione deficiency and peripheral metabolism of thyroid hormones during dietary cysteine deprivation in rats
}

\author{
By C. SUBERVILLE, P. HIGUERET, D. TARUOURA AND H. GARCIN* \\ Laboratoire Physiologie de la Nutrition, Département Alimentation et Nutrition, \\ Université de Bordeaux I, avenue des Facultés, 33405 Talence-Cédex, France \\ AND D. HIGUERET \\ Laboratoire Biochimie Médicale, Hôpital Pellegrin, Place Raba Léon, \\ 33000 Bordeaux, France
}

(Received 21 August 1987 -Accepted 22 December 1987)

1. For a period of $24 \mathrm{~d}$, young rats received a diet containing $120 \mathrm{~g}$ casein $/ \mathrm{kg}$ or the same basic diet supplemented with $1.93 \mathrm{~g}$ cysteine $/ \mathrm{kg}$.

2. The thyroxine $\left(\mathrm{T}_{4}\right)$ turnover was decreased in rats receiving the cysteine-deficient diet compared with that of rats on the supplemented diet. Moreover, the extrathyroidal $\mathrm{T}_{4}$ pool and $\mathrm{T}_{4}$ disposal rate decreased.

3. Cysteine deprivation also decreased the peripheral metabolism of $3,5,3^{\prime}$-triiodothyronine $\left(T_{3}\right)$. The $T_{3}$ distribution space, extrathyroidal pool of $T_{3}$ and $T_{3}$ disposal rate were diminished.

4. In vitro, deiodination of $T_{4}$ in liver homogenate assayed with endogenous glutathione (GSH) demonstrated decreased $T_{3}$ production rates in the case of cysteine deficiency. This difference was minimized by the addition of GSH in amounts sufficient to saturate the reaction kinetics. In the light of this finding, GSH is probably involved in the promotion of certain thyroidal problems induced by a cysteine-deficient diet.

Glutathione ( $\gamma$-L-glutamyl-L-cysteinyl-glycine; GSH) is a tripeptide which has many metabolic functions in the liver and kidney (for review, see Sies \& Wendel, 1978). For example, GSH is critical for thyroid hormone metabolism as it is the cofactor of the $5^{\prime}$ monodeiodinase (Type I) enzyme which catalyses the deiodination of thyroxine $\left(\mathrm{T}_{4}\right)$ to 3,5,3'-triiodothyronine $\left(\mathrm{T}_{3}\right.$ ) (Balsam \& Ingbar, 1978; Chopra, 1978; Imai et al. 1980; Higueret \& Garcin, 1982) and affects $\mathrm{T}_{3}$ cellular uptake (Higueret \& Garcin, 1984).

Nutritional conditions, such as the cysteine and methionine contents of the diet, influence the GSH content in tissues (Tateishi et al. 1981; Glazenburg et al. 1983; Suberville et al. 1987). Recently, we have shown that thyroidal diseases appeared in animals fed on an imbalanced diet which was deficient in either cysteine or cysteine and methionine (Suberville et al. 1987). In order to identify the precise mechanisms involved in changes. of hormonal status, we have studied some aspects of peripheral metabolism of thyroid hormones during dietary cysteine deprivation. Cysteine depletion was achieved with diets in which the protein source was casein at $120 \mathrm{~g} / \mathrm{kg}$. The control diet contained $120 \mathrm{~g}$ casein $/ \mathrm{kg}$ and was supplemented with $1.93 \mathrm{~g}$ cysteine $/ \mathrm{kg}$ which meets the minimum nutritional requirements for sulphur amino acids in the rat (Sowers et al. 1972).

\section{METHODS \\ Animals and diets}

Male Wistar rats with an initial weight of $110-120 \mathrm{~g}$ were obtained from IFFA Credo (France) and were fed for $24 \mathrm{~d}$ on one of the following semi-synthetic diets $(\mathrm{g} / \mathrm{kg})$ : casein 120, casein $120+\mathrm{L}$-cysteine 1.93 (Suberville et al. 1987). Animals were housed in an airconditioned room with a mean temperature of $21 \pm 1^{\circ}$, were weighed daily and the food 
intake calculated. Under these experimental conditions, as we have already shown (Suberville et al. 1987), the food intakes of the two groups of animals are similar.

At the end of the experimental period the rats were killed by decapitation at 09.00 hours and the livers rapidly excised. A portion was immediately used for GSH analysis, the remainder was frozen in liquid nitrogen and stored at $-80^{\circ}$ for subsequent analysis.

\section{In vivo metabolism of $T_{4}$ and $T_{3}$}

Turnover of thyroid hormones. The turnover of thyroid hormones was studied after blocking the thyroidal iodide pump with potassium iodide. At 0 time, animals were given subcutaneous injections of $5 \mu \mathrm{Ci}\left[{ }^{125} \mathrm{I}^{\mathrm{T}} \mathrm{T}_{4}\right.$ (IM 141; Amersham, France; specific activity $1.2 \mathrm{mCi} / \mathrm{mg}$ ) $/ \mathrm{kg}$ body-weight or $10 \mu \mathrm{Ci}\left[{ }^{125} \mathrm{I}\right] \mathrm{T}_{3}$ (IM 321; Amersham, France; specific activity $1.2 \mathrm{mCi} / \mu \mathrm{g}) / \mathrm{kg}$. At carefully timed intervals between 12 and $36 \mathrm{~h}$ after $\mathrm{T}_{4}$ injection, and between 3 and $24 \mathrm{~h}$ after $\mathrm{T}_{3}$ injection, blood samples were collected by venepuncture from the subclavian venous plexus (Higueret \& Garcin, 1982).

The treatment of serum containing $\left[{ }^{125} \mathrm{I}_{4}\right.$ (Geloso \& Bernard, 1967) or serum containing $\left[{ }^{125} \mathrm{I}\right] \mathrm{T}_{3}$ (Balsam et al. 1978) permitted the determination of the usual indices of peripheral metabolism of thyroid hormones (Ingenbleek \& Malvaux, 1980): $\mathrm{T}_{4}$ or $\mathrm{T}_{3}$ distribution space (TDS), which is the virtual space in which the tracer dose of hormone would be found if it were distributed at a concentration equal to that of plasma; extrathyroidal $T_{4}$ or $T_{3}$ pool (ETP), which is the quantity of exchangeable $T_{4}$ or $T_{3}$ within the organism; $\mathrm{T}_{4}$ or $\mathrm{T}_{3}$ fractional turnover rate $(K)$, which is the fraction of ETP replaced per unit time (this variable is calculated from the measured half-life $\left(t_{\frac{1}{2}}\right)\left(K=0 \cdot 693 / t_{\frac{1}{2}}\right)$; $\mathrm{T}_{4}$ or $\mathrm{T}_{3}$ disposal rate (TDR), which is the total hormone turnover.

Hormone assays. The assays were performed in duplicate on serum samples collected before initiation of turnover studies. Serum $\mathrm{T}_{4}$ was determined by the competitive-binding assay of Murphy \& Jachan (1965), adapted by Vigouroux (1972). Serum $\mathrm{T}_{3}$ was determined by the specific double-antibody radioimmunoassay of Chopra et al. (1972) adapted by Jordan et al. (1980).

\section{In vitro generation of $T_{3}$ from $T_{4}$ in liver homogenates}

5 -Monodeiodinase activity was measured in liver homogenates by high-performance liquid chromatography (HPLC) of $\mathrm{T}_{4}$ and $\mathrm{T}_{3}$

Preparation of tissue fraction. Portions of liver were homogenized $(1: 2, \mathrm{w} / \mathrm{v})$ in $0 \cdot 1 \mathrm{M}$-Tris buffer $\left(\mathrm{pH} 7.4,4^{\circ}\right)$ and centrifuged at $9000 \mathrm{~g}$ for $4 \mathrm{~min}$. The formation of $\mathrm{T}_{3}$ was measured in the supernatant fractions by a modified method of Scammel et al. (1986).

Incubation and extraction conditions. Portions $(100 \mu)$ of the supernatant fraction were incubated for $30 \mathrm{~min}$ at $37^{\circ}$ with $\mathrm{T}_{4}(6.4 \mu \mathrm{M}),\left[{ }^{125} \mathrm{I}\right] \mathrm{T}_{4}(0.5 \mu \mathrm{Ci}$; specific activity of hormone $1.2 \mathrm{mCi} / \mathrm{mg}$ ) and with or without reduced GSH $(4.6 \mathrm{~mm})$. The reaction was stopped by the addition of $2 \cdot 3 \mathrm{vol}$. methanol which also served to extract the thyroid hormones. After centrifugation, the supernatant fraction was held at $-30^{\circ}$ overnight and recentrifuged before analysis. Non-enzymic formation of $T_{3}$ was measured by incubation of the reaction mixture at $37^{\circ}$ without liver homogenate: cold liver homogenate was added following incubation and thyroid hormones immediately extracted. Studies of the efficiency of extraction of $\left[{ }^{125} \mathrm{I}\right] \mathrm{T}_{3}$ or $\left[{ }^{[25} \mathrm{I}\right] \mathrm{T}_{4}$ added to liver homogenates indicated that $97(\mathrm{SE} 2) \%$ of radioactivity was extracted under these conditions.

Hormone separation. $\mathrm{T}_{4}$ and $\mathrm{T}_{3}$ were separated by an HPLC method modified from that of Hearn et al. (1978). The precise conditions were: column ultra-sphere ODS Beckman, $5 \mu \mathrm{m}$ internal diameter, $250 \mathrm{~mm}$ length; mobil phase methanol:phosphoric acid $(1 \mathrm{ml} / 1$ distilled-deionized water) $(70: 30, \mathrm{v} / \mathrm{v})$; u.v. detection at $254 \mathrm{~nm}$. The reaction products potentially quantified by this method are $T_{3}$, reverse $T_{3}\left(\mathrm{rT}_{3}\right)$ and 3,5-diiodothyronine 


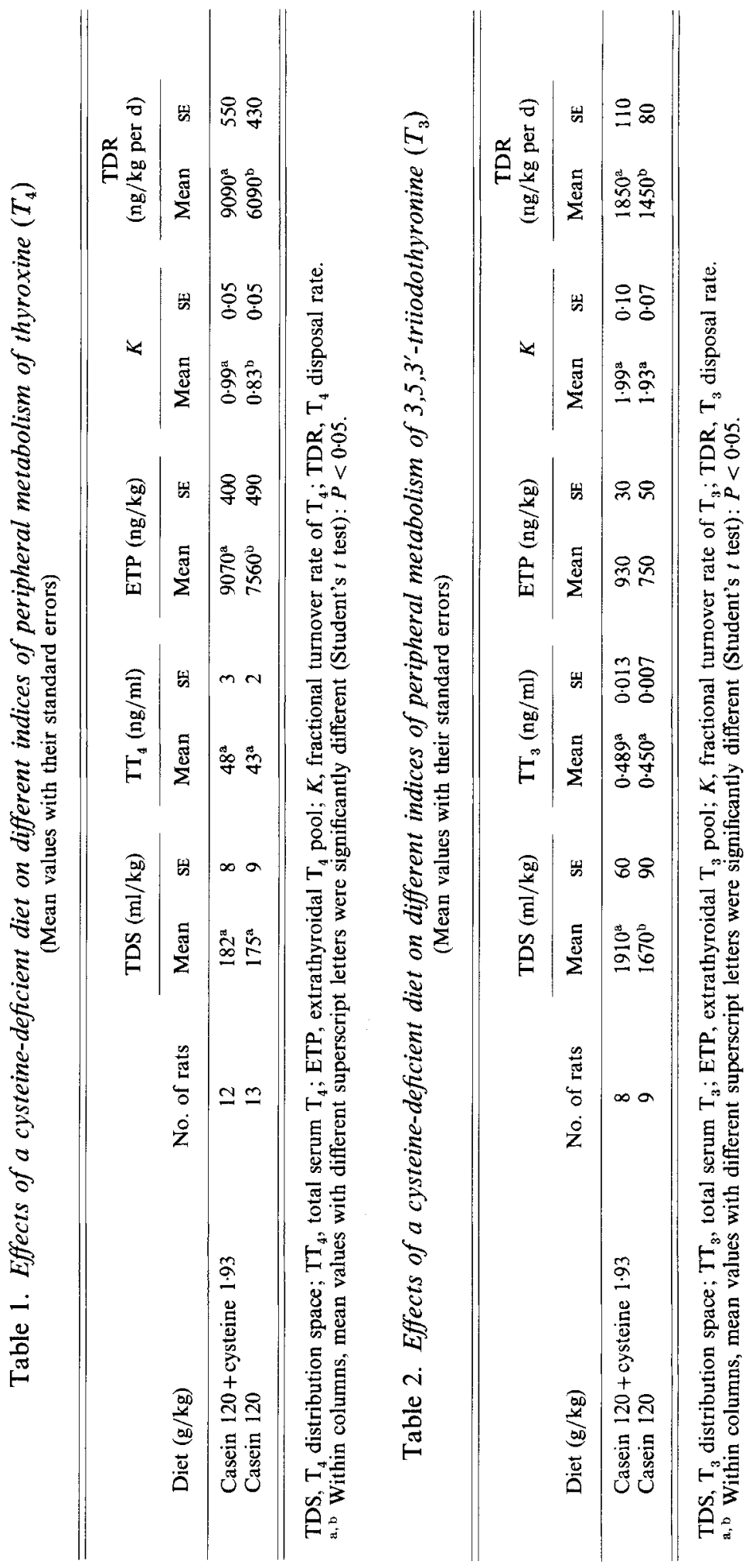


Table 3. Effects of a cysteine-deficient diet on hepatic 3,5,3'-triiodothyronine $\left(T_{3}\right)$ generation

(Mean values with their standard errors)

\begin{tabular}{|c|c|c|c|c|c|c|c|}
\hline \multirow[b]{3}{*}{ Diet $(g / k g)$} & \multirow[b]{3}{*}{ No. of rats } & \multirow{2}{*}{\multicolumn{2}{|c|}{$\begin{array}{l}\text { Liver GSH } \\
(\mu \mathrm{mol} / \mathrm{g})\end{array}$}} & \multicolumn{4}{|c|}{$\begin{array}{c}{\left[{ }^{125} \mathrm{l}\right] \mathrm{T}_{3} \text { formation }} \\
(\mathrm{fmol} / \mathrm{mg} \text { protein per } \mathrm{min})\end{array}$} \\
\hline & & & & \multicolumn{2}{|c|}{ Basal } & \multicolumn{2}{|c|}{ With $4.6 \mathrm{~mm}-\mathrm{GSH}$} \\
\hline & & Mean & $\mathrm{SE}$ & Mean & $\mathrm{SE}$ & Mean & $\mathrm{SE}$ \\
\hline Casein $120+$ cysteine 1.93 & 8 & $4 \cdot 45^{a}$ & 0.24 & $44^{a}$ & 4 & $58^{\mathrm{a}}$ & 6 \\
\hline Casein 120 & 8 & $2 \cdot 17^{b}$ & $0 \cdot 11$ & $31^{\mathrm{b}}$ & 1 & $45^{\mathrm{a}}$ & 4 \\
\hline
\end{tabular}

GSH, glutathione.

${ }^{a}, b$ Within columns, mean values with different superscript letters were significantly different (Student's $t$ test): $P<0.05$.

$\left(T_{2}\right)$. Under the conditions of the present study, however, only negligible amounts of $r T_{3}$ and $T_{2}$ occurred and the results are expressed as fmol $T_{3}$ produced/mg protein per min.

\section{Protein assay}

Protein concentration of the homogenates was measured according to Bradford (1976) using the Bio-Rad protein assay (Bio-Rad Laboratories, West Germany).

\section{Reduced GSH assay}

Sample GSH was preserved with vinyl-2-pyridine (Griffith, 1980). GSH was measured enzymically according to Tietze's (1969) method, using glutathione reductase $(E C$ 1.6.4.2) and 5,5'-dithiobis(2-nitrobenzoic) acid.

\section{RESULTS}

In vivo peripheral metabolism of $T_{4}$

The study of biological $t_{\frac{1}{2}}$ of $\mathrm{T}_{4}$ in rats fed on a cysteine-deficient diet showed that $t_{\frac{1}{2}}$ was extended in relation to that of controls (20 (SE 1) v. 17.0 (SE 0.8) h). Table 1 summarizes the results of the $T_{4}$ turnover study. TDS, which is essentially the extracellular compartment, was not affected by the cysteine-deficient diet. However we observed a $16 \%$ decrease in ETP which is the quantity of exchangeable $\mathrm{T}_{4}$ within the organism, and a great decrease $(-33 \%)$ in TDR which corresponds to the rate of total $T_{4}$ turnover.

\section{In vivo peripheral metabolism of $T_{3}$}

The biological $t_{\frac{1}{2}}$ of $\mathrm{T}_{3}$ was not modified by the cysteine-deficient diet (8.7 (SE 0.37 ) v. 8.5 (sE 0.45) h for control diet). The values for $T_{3}$ turnover indices are presented in Table 2 . TDS for $T_{3}$ was greater than that of $T_{4}$ because its cellular internalization rate and consequently its cellular concentration is greater (De Groot, 1979). In the animals receiving the cysteinedeficient diet, the TDS was significantly decreased $(-13 \%)$ in comparison with that of controls. ETP for $\mathrm{T}_{3}$ was decreased $(-19 \%)$ in rats fed on a cysteine-deficient diet. The findings suggest a change in peripheral metabolism of $\mathrm{T}_{4}$ which constitutes the major source of $\mathrm{T}_{3}$ in man and experimental animals (Chopra et al. 1982). For $\mathrm{T}_{4}$, we observed a decrease $(-22 \%)$ in TDR in rats which received the cysteine-deficient diet compared with control rats. 


\section{In vitro generation of $T_{3}$ from $T_{4}$ and the influence of $G S H$}

As can be seen in Table 3, the cysteine-deficient diet caused a great decrease $(-51 \%)$ in hepatic GSH. Under basal conditions, i.e. in the absence of GSH in the reaction mixture, the $\left[{ }^{125} \mathrm{I}\right] \mathrm{T}_{3}$ formation by the liver was less $(-30 \%)$ in rats fed on the cysteine-deficient diet. After addition of GSH to the incubation medium, $\mathrm{T}_{3}$ generation was increased in the two groups of rats $(32 \%$ increase in controls, $45 \%$ increase in cysteine-deficient animals). However, liver $\mathrm{T}_{3}$ generation was not significantly different between the two groups of animals when GSH was added to the medium as a cofactor.

\section{DISCUSSION}

The decrease in $\mathrm{T}_{4}$ ETP observed in rats which received the cysteine-deficient diet would suggest an alteration of thyroid hormone synthesis. The molecular structure of thyroglobulin includes many half-cystine residues forming intrachain or interchain disulphide bonds (De Crombrugghe et al. 1966), more particularly at the carboxyl-end of the protein (Di Lauro et al. 1984). Recently it was demonstrated that hormogenic sites are located at the extremities of thyroglobulin (Lejeune et al. 1983; Rawitch et al. 1984). Possibly cysteine depletion caused by the diet led to a change in thyroglobulin which affected $\mathrm{T}_{4}$ biosynthesis.

The decreased TDR in the rats fed on the cysteine-deficient diet is consistent with an alteration of peripheral metabolism of $\mathrm{T}_{4} . \mathrm{T}_{4}$ is metabolized primarily by deiodination, mainly in the liver and kidney (for review, see Köhrle et al. 1987). The extrathyroidal 5'monodeiodination of $T_{4}$ to $T_{3}$ is enzymic in nature (Visser et al. 1976) and relies on GSH as a cofactor (Imai et al. 1980). The decrease in $T_{4}$ deiodination as well as the decrease in hepatic GSH observed in our experiments tend to confirm this explanation. The decrease in hepatic GSH found in rats fed on the unsupplemented diet is presumed to be the result of cysteine insufficiency for the biosynthesis of this tripeptide ( $\gamma$-L-glutamyl-L-cysteinylglycine). Moreover, GSH is well-known as a cysteine reservoir during cystine depletion in growing rats (Cho et al. 1984).

5'-Monodeiodination of $\mathrm{T}_{4}$ to $\mathrm{T}_{3}$ by peripheral tissues accounts for most of the daily production of $T_{3}$ in the rat (Abrams \& Larsen, 1973). Studies using homogenates have shown that on a per gram basis liver and kidney are much more potent in monodeiodination of $T_{4}$ to $T_{3}$ than other tissues (Chopra et al. 1978). In whole-body terms, liver is the most important source of $T_{3}$ in peripheral tissues. The decrease in this metabolic pathway in the rats fed on the cysteine-deficient diet explains the diminution of $T_{3}$ ETP observed in these animals. $T_{3}$ is converted to $3,3^{\prime}-\mathrm{T}_{2}$ and $3,5-\mathrm{T}_{2}$ (diiodothyronine) by an enzymic monodeiodination (Chopra et al. 1978) and a slowing down of these reactions may be responsible for the decrease in TDR found in the animals fed on the unsupplemented diet.

With regard to TDS, the $T_{3}$ distribution in the body is essentially intracellular. The $T_{3}$ uptake by target cells is the result of active mechanisms (Rao et al. 1976; Cheng, 1983). However, we have shown that GSH was involved in cellular $\mathrm{T}_{3}$ uptake. A decrease in intracellular GSH leads to a reduction in the $T_{3}$ penetration of cells (Higueret \& Garcin, 1984). In the present experiment the hepatic GSH is decreased and therefore a decrease in $\mathrm{T}_{3}$ TDS would not be unexpected. The cysteine-deficient diet caused a tissue deficiency of sulphydryl groups, the consequences of which may be translated into various effects on thyroid hormone metabolism. It is now necessary to determine if the hormonal metabolic changes observed have effects on the amount of free $T_{3}$, which is the biologically active form of the thyroid hormones. 
The authors are grateful to Dr P. A. Spear (University of Ottawa, Ontario, Canada) for his help with the in vitro $\mathrm{T}_{3}$ generation study during his stay in the laboratory.

\section{REFERENCES}

Abrams, G. M. \& Larsen, P. R. (1973). Journal of Clinical Investigation 52, 2522-2531.

Balsam, A., Eisenstein, Z., Sexton, F. \& Ingbar, S. H. (1978). Endocrinology 102, 1247-1253.

Balsam, A. \& Ingbar, S. H. (1978). Clinical Research 26, 489A.

Bradford, M. (1976). Analytical Biochemistry 72, 248-254.

Cheng, S. Y. (1983). Endocrinology 112, 1754-1762.

Cho, E. S., Johnson, N. \& Snider, B. C. F. (1984). Journal of Nutrition 114, 1853-1862.

Chopra, I. J. (1978). Science 199, 904-906.

Chopra, I. J., Chua Teco, G. N., Eisenberg, J. B., Wiersinga, W. M. \& Solomon, D. H. (1982). Endocrinology 110 , 163-168.

Chopra, I. J., Ho, R. S. \& Lan, R. (1972). Journal of Laboratory and Clinical Medicine 80, 729-739.

Chopra, I. J., Solomon, D. H., Chopra, U., Wu, S. Y., Fisher, D. A. \& Nakamura, Y. (1978). Recent Progress in Hormone Research 34, 521-567.

De Crombrugghe, B., Pitt Rivers, R. \& Edelhoch, H. (1966). Journal of Biological Chemistry 241, $2766-2773$.

De Groot, L. J. (1979). In Free Thyroid Hormones, pp. 632-635 [R. Ekins, G. Faglia, F. Pennisi and A. Pinchera, editors]. Amsterdam, Oxford and Princeton: Excerpta Medica.

Di Lauro, R., Obici, S., Condliffe, D., Ursini, V. M., Musti, A., Moscatelli, C. \& Avvedimento, V. E. (1984). European Journal of Biochemistry 148, 7-11.

Geloso, J. P. \& Bernard, G. (1967). Acta Endocrinologica 56, 561-566.

Glazenburg, E. J., Jeckel-Halsema, I. M. C., Scholtens, E., Baars, A. J. \& Mulder, G. J. (1983). Journal of Nutrition 113, 1363-1373.

Griffith, O. W. (1980). Analytical Biochemistry 106, 207-212.

Hearn, M. T. W., Hancock, W. S. \& Bishop, C. A. (1978). Journal of Chromatography 157, 337-343.

Higueret, P. \& Garcin, H. (1982). Annals of Nutrition and Metabolism 26, 191-200.

Higueret, P. \& Garcin, H. (1984). Annales d'Endocrinologie 45, 149-150.

Imai, Y., Kataoka, N. \& Nishikimi, M. (1980). Endocrinologia Japonica 27, 201-207.

Ingenbleek, Y. \& Malvaux, P. (1980). American Journal of Clinical Nutrition 33, 609-616.

Jordan, D., Rousset, B., Perrin, F., Fournier, M. \& Orgiazzi, J. (1980). Endocrinology 107, 1245-1248.

Köhrle, G., Brabant, R. \& Hesh, D. (1987). Hormone Research 26, 58-78.

Lejeune, P. J., Marriq, C., Rolland, M. \& Lissitky, S. (1983). Biochemical and Biophysical Research Communications 114, 73-80.

Murphy, B. P. \& Jachan, C. (1965). Journal of Laboratory and Clinical Medicine 66, 161-167.

Rao, S. G., Eckel, J., Rao, M. L. \& Brever, M. (1976). Biochemical and Biophysical Research Communications 73 , 98-104.

Rawitch, A. B., Litwer, M. R., Gregg, J., Turner, C. D., Rouse, J. B. \& Hamilton, Y. W. (1984). Biochemical and Biophysical Research Communications 118, 423-428.

Scammel, J. G., Shiverick, K. T. \& Fregly, M. J. (1986). Pharmacology 33, 52-57.

Sies, H. \& Wendel, A. (1978). Functions of Glutathione in Liver and Kidney. Berlin, Heidelberg and New York: Springer-Verlag.

Sowers, J. E., Stockland, W. L. \& Meade, R. J. (1972). Journal of Animal Science 35, 782-788.

Suberville, C., Higueret, P., Taruoura, D., Higueret, D. \& Garcin, H. (1987). British Journal of Nutrition 58, $105-111$.

Tateishi, N., Higashi, T., Naruse, A., Hikita, K. \& Sakamoto, Y. (1981). Journal of Biochemistry 90 , $1603-1610$.

Tietze, F. (1969). Analytical Biochemistry 27, 502-522.

Vigouroux, E. (1972). Comptes Rendus Hebdomadaires des Séances de l'Académie des Sciences, Paris 275, 579-582.

Visser, T. J., Van der Does-Tobe, T., Docter, R. \& Henneman, G. (1976). Biochemical Journal 157, 479-482. 